\title{
25. GEOCHEMISTRY OF CARBON: DEEP SEA DRILLING PROJECT SITES 415 AND 416
}

\author{
K.S. Schorno and J.G. Erdman, Phillips Petroleum Company, Bartlesville, Oklahoma
}

\section{INTRODUCTION}

Eight frozen core sections from DSDP-IPOD Leg 50 were provided by the JOIDES Advisory Panel for organic-geochemistry studies. The samples were collected from Holes 415 and $416 \mathrm{~A}$, which were drilled off the coast of northwest Africa (Figure 1). All but one of the samples are Hauterivian to Valanginian claystone taken from Hole $416 \mathrm{~A}$ from a subsea depth of 1180.0 to 1532.3 meters on the continental margin west of Morocco. The single sample from Hole 415 consists of middle Miocene marl cored at $\mathbf{2 0 9 . 5}$ meters on the southern flank of the Agadir Canyon.

\section{SAMPLING AND STUDY PROCEDURES}

The sampling and analysis procedures used in this laboratory for DSDP cores have been described in the Initial Reports for Leg 44 (Erdman and Schorno, $1978 \mathrm{c})$. In the case of the Leg 50 samples, however, the usual analyses were not possible because of the friable nature and lack of soluble organic matter in the samples. In the past we determined core disturbance and sediment mixing by milling a flat surface of the frozen section and visually inspecting the milled surface for lithologic variation. We also usually removed the surface of the core next to the core liner to eliminate possible contamination from the liner. We were unable to perform either of these operations on the Leg 50 material, however, because the cores were too friable. Consequently, trace amounts of the phthalate esters, presumably plasticizers, were detected in several cores. The effects of these contaminants, however, were minimal.

Despite the paucity of soluble organic matter (lipid), we determined the carbon-isotope composition, gaschromatography profile, and carbon, hydrogen, and nitrogen compositions from this fraction. Although the ratio of odd to even carbon number $n$-alkanes in the $\mathrm{C}_{25}$ to $\mathrm{C}_{33}$ range ( $\overline{\mathrm{OEP}}$ ) could not be determined by the usual urea adduction procedure, these values were calculated from $n$-alkanes present in the gas-chromatography profile $^{1}$ of the lipid fraction. Because the resolution of these $n$-alkanes is poor, these values are only approximate.

\section{RESULTS AND DISCUSSION}

The numerical data for organic carbon, lipid, and carbon-isotope composition of the lipid and kerogen fractions along with sub-bottom depths and chrono-

\footnotetext{
${ }^{1}$ Gas-chromatography profiles were obtained on the $n$-heptane soluble lipid fraction using a $4^{\prime}$ by $1 / 4^{\prime \prime} 3 \%$ DEXSIL 300 on $100 / 120$ mesh Suplecoport glass column programmed from $90^{\circ}$ to $340^{\circ}$ at $8 \%$ min.
}

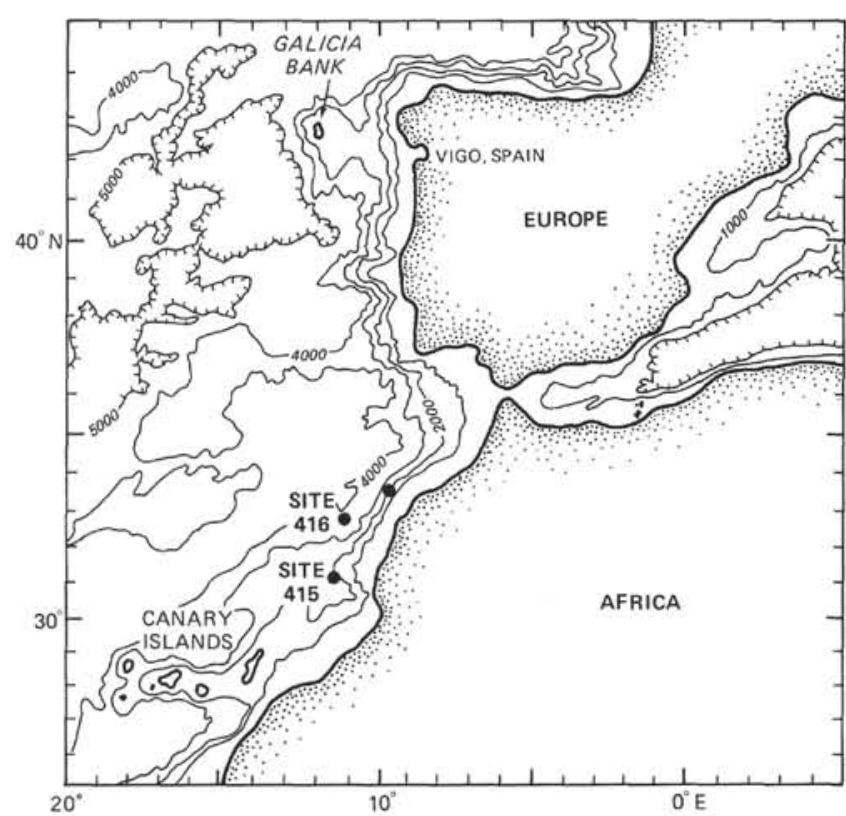

Figure 1. Location of Leg 50 holes from which samples for geochemical study were obtained.

stratigraphy of the samples are given in Table 1 . Table 2 contains the nitrogen composition of the bulk rock and carbon, hydrogen, and nitrogen compositions of lipids both from this leg as well as from Leg 40 (Erdman and Schorno, 1978a, b). Table 3 shows the nitrogen contents and the carbon-isotope compositions of the lipids for cores from Legs $40,41,48$, and 50 .

These sediments are of terrestrial origin and were introduced into a deep-ocean environment by turbidity flows (Site 415 and 416 reports, this volume). On the basis of thermal-analysis data (this volume), the organic matter deposited with these sediments is also terrestrial. We have attempted to determine the origin of these sediments by other independent methods which are discussed in the following paragraphs.

The organic-carbon content for the eight cores from both Holes 415 and $416 \mathrm{~A}$ averages 0.28 per cent. Although this is slightly above the 0.1 average of deepocean sediments, it is well below the average of 0.8 per cent reported in the Site 416 report. As the content of organic matter as reported in the Site 416 report fluctuates considerably within narrow depth intervals, the discrepancies between our values and those obtained aboard ship may reflect the small sampling used in our calculations.

The carbon, hydrogen, and nitrogen compositions of Hole 415 and 416A lipids are considerably different. The composition of the lipid from Hole 415 is typical of 
TABLE 1

Geochemical Data on Samples from Sites 415 and 416

\begin{tabular}{|c|c|c|c|c|c|c|c|c|c|c|c|}
\hline \multirow[b]{2}{*}{$\begin{array}{c}\text { Sample } \\
\text { (Interval in } \mathrm{cm} \text { ) }\end{array}$} & \multirow[b]{2}{*}{ Chronostratigraphy } & \multirow{2}{*}{$\begin{array}{l}\text { Sub-Bottom } \\
\text { Depth } \\
\text { (m) }\end{array}$} & \multicolumn{2}{|c|}{ Carbonate } & \multicolumn{2}{|c|}{ Organic Carbon } & \multirow{2}{*}{$\begin{array}{l}\text { Lipid/ } \\
\text { Total } \\
\text { Carbon } \\
\text { (wt. \%) }\end{array}$} & \multirow{2}{*}{\multicolumn{3}{|c|}{$\begin{array}{l}\text { Carbon-Isotope, } \\
\text { Composition } \\
\left({ }^{1}{ }^{13} \text { C } \mathrm{PDB}\right)\end{array}$}} & \multirow[b]{2}{*}{$\overline{\mathrm{OEP}}$} \\
\hline & & & $\begin{array}{l}\text { Carbon } \\
\text { (wt. \%) }\end{array}$ & $\begin{array}{l}\mathrm{CaCO}_{3} \\
\text { (wt. \%) }\end{array}$ & $\begin{array}{l}\text { Total } \\
\text { (wt. \%) }\end{array}$ & $\begin{array}{l}\text { Lipid } \\
\text { (ppm) }\end{array}$ & & & & L-K & \\
\hline \multicolumn{12}{|l|}{ Hole 415} \\
\hline $42,103-106$ & Middle Miocene & 209.53-210.00 & 6.4 & 53 & 0.13 & 182 & 14 & -28.5 & -27.8 & -0.7 & \\
\hline \multicolumn{12}{|c|}{ Hole $416 \mathrm{~A}$, Unit VI ( 880 to $1428 \mathrm{~m}$ ) } \\
\hline $\begin{array}{l}9-2,122-132 \\
14-4,98-111 \\
18-3,119-132 \\
23-3,146-150 \\
28-4,100-112\end{array}$ & $\begin{array}{l}\text { Hauterivian } \\
\text { Valanginian } \\
\text { Valanginian } \\
\text { Valanginian } \\
\text { Valanginian }\end{array}$ & $\begin{array}{l}1179.62-1179.72 \\
1227.76-1228.00 \\
1265.91-1267.75 \\
1312.94-1313.10 \\
1361.81-1361.95\end{array}$ & $\begin{array}{l}1.2 \\
2.1 \\
1.8 \\
1.9 \\
1.9\end{array}$ & $\begin{array}{l}10 \\
17 \\
15 \\
16 \\
16\end{array}$ & $\begin{array}{l}0.17 \\
0.45 \\
0.55 \\
0.48 \\
0.23\end{array}$ & $\begin{array}{l}18 \\
38 \\
51 \\
43 \\
19\end{array}$ & $\begin{array}{l}1.1 \\
0.8 \\
0.9 \\
0.9 \\
0.8\end{array}$ & $\begin{array}{l}-27.8 \\
-28.6 \\
-29.2 \\
-28.8 \\
-27.7\end{array}$ & $\begin{array}{l}-27.3 \\
-26.3 \\
-27.3 \\
-26.9 \\
-26.6\end{array}$ & $\begin{array}{l}-0.5 \\
-2.3 \\
-2.0 \\
-1.9 \\
-1.1\end{array}$ & 2.9 \\
\hline \multicolumn{12}{|c|}{ Hole $416 \mathrm{~A}$, Unit VII (1428 to $1624 \mathrm{~m}$ ) } \\
\hline $\begin{array}{l}42-2,22-32 \\
48-2,104-114\end{array}$ & $\begin{array}{l}\text { Valanginian } \\
\text { Valanginian }\end{array}$ & $\begin{array}{l}1475.02-1475.13 \\
1532.16-1532.31\end{array}$ & $\begin{array}{l}2.0 \\
1.0\end{array}$ & $\begin{array}{r}17 \\
8\end{array}$ & $\begin{array}{l}0.04 \\
0.14\end{array}$ & $\begin{array}{r}4 \\
12\end{array}$ & $\begin{array}{l}1.0 \\
0.9\end{array}$ & $\begin{array}{l}-26.9 \\
-26.8\end{array}$ & $\begin{array}{l}-25.7 \\
-25.4\end{array}$ & $\begin{array}{l}-1.2 \\
-1.4\end{array}$ & 1.5 \\
\hline
\end{tabular}

TABLE 2

Nitrogen Composition of Total Rock and Carbon, Hydrogen, and Nitrogen Composition of Lipid

\begin{tabular}{|c|c|c|c|c|c|c|c|c|c|}
\hline \multirow[b]{3}{*}{$\begin{array}{c}\text { Sample } \\
\text { (Interval in } \mathrm{cm} \text { ) }\end{array}$} & \multicolumn{4}{|c|}{ Composition of Total Rock } & \multirow{2}{*}{\multicolumn{5}{|c|}{ Composition of Lipid }} \\
\hline & \multicolumn{3}{|c|}{ Kjeldalh Nitrogen (ppm) } & \multirow{2}{*}{$\begin{array}{l}\text { Atomic Ratio } \\
\text { Organic C/ } \\
\text { Organic N }\end{array}$} & & & & & \\
\hline & $\begin{array}{c}\text { Half } \\
\text { Ammonium N }\end{array}$ & $\begin{array}{c}\text { Full } \\
\text { Total N }\end{array}$ & $\begin{array}{c}\mathrm{F}-\mathrm{H} \\
\text { Organic N }\end{array}$ & & $\underline{\mathrm{C}}$ & $\frac{\mathrm{H}}{(\%)}$ & $\underline{N}$ & $\mathrm{H} / \mathrm{C}$ & $\mathrm{C} / \mathrm{N}$ \\
\hline Hole 415 & & & & & & & & & \\
\hline $4-2,103-106$ & 60 & 389 & 329 & 5 & 86.2 & 13.1 & 0.7 & 1.82 & 143 \\
\hline \multicolumn{10}{|c|}{ Hole 416A, Unit VI (880-1424 m) } \\
\hline $\begin{array}{l}9-2,122-132 \\
14-4,98-111 \\
18-3,119-132 \\
23-3,146-150 \\
28-4,100-112 \\
\text { Average }\end{array}$ & $\begin{array}{r}70 \\
100 \\
100 \\
80 \\
90 \\
88\end{array}$ & $\begin{array}{l}481 \\
652 \\
678 \\
677 \\
512 \\
600\end{array}$ & $\begin{array}{l}411 \\
552 \\
578 \\
597 \\
422 \\
512\end{array}$ & $\begin{array}{r}5 \\
10 \\
11 \\
10 \\
6 \\
8\end{array}$ & $\begin{array}{l}7 \overline{79.2} \\
78.2 \\
77.6 \\
74.9 \\
77.5\end{array}$ & $\begin{array}{r}- \\
\overline{-} \\
9.7 \\
10.0 \\
9.7 \\
9.8\end{array}$ & $\begin{array}{l}- \\
- \\
0.7 \\
0.5 \\
0.7 \\
0.6\end{array}$ & $\begin{array}{l}- \\
- \\
1.49 \\
1.55 \\
1.56 \\
1.53\end{array}$ & $\begin{array}{l}- \\
\overline{130} \\
181 \\
125 \\
145\end{array}$ \\
\hline \multicolumn{10}{|c|}{ Hole 416A, Unit VII (1428-1624 m) } \\
\hline $\begin{array}{l}42-2,22-32 \\
48-2,104-114 \\
\text { Average }\end{array}$ & $\begin{array}{l}80 \\
70 \\
75\end{array}$ & $\begin{array}{l}595 \\
412 \\
504\end{array}$ & $\begin{array}{l}515 \\
342 \\
429\end{array}$ & $\begin{array}{l}1 \\
5 \\
3\end{array}$ & $\begin{array}{l}- \\
-\end{array}$ & $\begin{array}{l}- \\
-\end{array}$ & $\begin{array}{l}- \\
-\end{array}$ & $\begin{array}{l}- \\
- \\
-\end{array}$ & $\begin{array}{l}- \\
-\end{array}$ \\
\hline
\end{tabular}

Average Value for 8 Cores from the Cape Basin, Leg 40, Hole 361 (1036.3-1221.8 m)

\begin{tabular}{l|llll|lllll}
361 & 56 & 1200 & 1143 & 444 & 80.4 & 9.4 & 0.5 & 1.40 & 187
\end{tabular}

Average Value for 8 Cores from Walvis Ridge, Leg 40, Hole 362 (43.3-185.8 m)

\begin{tabular}{l|llll|lllll}
362 & 190 & 2825 & 2635 & 16 & 78.2 & 11.6 & 0.6 & 1.78 & 152 \\
\hline
\end{tabular}

a highly saturated oil, as indicated by a $\mathrm{H} / \mathrm{C}$ ratio of 1.8. The lipid from the Hole $416 \mathrm{~A}$ cores is less saturated, as indicated by a $\mathrm{H} / \mathrm{C}$ ratio of 1.5 . The compositions of carbon, hydrogen, and nitrogen are similar in these lipids to those from turbidite sources such as those from Leg 40, Site 361 in the Cape Basin. Although the total organic-nitrogen content of the Hole 416A material is much lower than that from the Cape Basin, the carbon, hydrogen, and nitrogen contents are similar and differ from the contents of open-ocean sediments such as those of the Walvis Ridge.
If the content of organic nitrogen in these sediments is dependent on the source of the organic matter (terrestrial or marine), then the atomic ratio of organic carbon to organic nitrogen $(\mathrm{C} / \mathrm{N})$ should be diagnostic of the origin. The $\mathrm{C} / \mathrm{N}$ ratio varies from 1 to 11 for the eight cores studied. These values are low and the range is small as compared to the $\mathrm{C} / \mathrm{N}$ values of 62 cores from Legs 40, 41, and 48 (Ereman and Schorno, in press). Even though the range is small, we detect a trend in these values. The $\mathrm{C} / \mathrm{N}$ ratio increases with increase in organic-carbon content and decrease in $\delta^{13} \mathrm{C}$ of the lipid. 
TABLE 3

Atomic Ratio of Organic Carbon to Organic Nitrogen $(\mathrm{C} / \mathrm{N})$ and Carbon-Isotope

Composition of Lipid in Samples from Legs $40,41,48$, and 50

\begin{tabular}{lccc}
\hline Leg-Hole & $\begin{array}{c}\text { No. of } \\
\text { Samples }\end{array}$ & $\begin{array}{c}\text { Average Lipid } \\
\delta{ }^{1} \text { CPDB }\end{array}$ & $\begin{array}{c}\text { Average } \\
\text { C/N }\end{array}$ \\
\hline $40-361$ & 15 & -27.4 & 47 \\
$40-362$ & 19 & -23.8 & 14 \\
$40-362 \mathrm{~A}$ & 5 & -26.4 & 40 \\
$41-368$ & 11 & -27.0 & 89 \\
$48-402 \mathrm{~A}$ & 8 & -28.5 & 57 \\
$48-403$ & 2 & -28.5 & 24 \\
$48-404$ & 2 & -28.4 & 18 \\
$50-415$ & 1 & -28.5 & 5 \\
$50-416 \mathrm{~A}$ & 7 & -28.0 & 7 \\
\hline
\end{tabular}

The change in the $\mathrm{C} / \mathrm{N}$ ratio suggests a slight change in composition of the total organic matter. The change of $\mathrm{C} / \mathrm{N}$ values does not necessarily indicate an origin change. The range of $\mathrm{C} / \mathrm{N}$ values for open-ocean sediments appears to be narrow ( 1 to 30 ; Table 3 ). For sediments containing a higher content of terrestrial material, the range is wide and overlaps the values for open-ocean sediments (1 to 422$)$. These ratios suggest that $\mathrm{C} / \mathrm{N}$ values alone cannot be used to indicate the origin of sedimentary organic matter.

In contrast, the carbon-isotope composition of the lipid is diagnostic of source. Owing to the discrimination of ${ }^{12} \mathrm{C}$ from ${ }^{13} \mathrm{C}$ in dissolved carbon dioxide in sea water, marine organic matter is generally heavier than terrestrial organic matter. Therefore, a trend toward either lighter or heavier carbon-isotope composition of the lipid indicates a change in the proportions of terrestrial or marine organic matter, respectively. The carbon-isotope composition of the lipids from Hole $416 \mathrm{~A}$, reported as $\delta^{13} \mathrm{C}_{\mathrm{PDB}}$, is -27.8 for Section $416 \mathrm{~A}$ 9-2 at 1180.0 meters sub-bottom. ${ }^{2}$ It decreases to a low of -29.2 in Section 416A-18-3 at 1267.7 meters, and increases to a high of -26.8 in Section 416A-48-2 further downhole at 1532.16 meters. This variation suggests a periodic change in the influx of terrestrial organic matter during deposition. This trend also corresponds to trends in the $\mathrm{C} / \mathrm{N}$ ratio and organic-carbon content, indicating that all three parameters are genetically related and are related to periods of increased deposition.

Another ratio diagnostic of the origin of the organic matter is

$$
\frac{n-\mathrm{C}_{21}+n-\mathrm{C}_{22}}{n-\mathrm{C}_{22}+n-\mathrm{C}_{29}}
$$

(Philippi, 1974). This ratio is near unity in the Hole $416 \mathrm{~A}$ sediments which are typical of sediments containing a large portion of terrestrial organic matter. The ranges reported by Philippi are 0.6 to 1.2 for sediments

$$
{ }^{13} \mathrm{C}_{\mathrm{PDB}}=\frac{\left(R_{s}-R_{2}\right)}{R_{r}} \times 1000
$$

where $R_{r}$ pertains to a belemnite from the Upper Cretaceous Peedee Formation of South Carolina which has a ${ }^{12} \mathrm{C} /{ }^{13} \mathrm{C}=88.99$. from terrestrial sources and 1.5 to 5 for those from marine sources.

Because of the paucity of lipid within most of the Leg 50 sediments and the poor resolution of $n$-alkanes in the gc-profiles of these lipids, organic diagenesis or maturity $(\overline{\mathrm{OEP}})$ was measured on only two of the eight cores studied. Nevertheless, maturity appears to increase significantly with depth. Diagenesis is in an early stage in the Hauterivian to at least the Valanginian sediments at 1312.9 meters, as suggested by a relatively high $\overline{\mathrm{OEP}}$ value of 2.9. Although still incomplete, diagenesis is much further advanced further downhole in the lower part of the Valanginian sediments of Section 416A-48-2, to at least 1532.16 meters. The $\overline{\mathrm{OEP}}$ value here is 1.5 , compared to less than 1.3 for mature petroleum source rocks. These conclusions are in agreement with the results of thermal analysis reported in the site reports of this volume.

\section{CONCLUSIONS}

All the studied samples are slightly richer in organic carbon than the average deep-ocean sediment, but contain less than the 0.5 per cent organic carbon considered necessary for the generation of petroleum. The lipid in these cores appears to be derived from both marine and terrestrial sources. We infer from the carbon-isotope composition of the lipid fraction that variations occurred in the ratio of terrestrial to marine contribution into these sediments during the time the Hole 416A sediments were deposited. Organic diagenesis is not far advanced in the middle Miocene Core from Hole 415 or in the Hauterivian to Valanginian cores of Hole 416A. In the lower part of the Valanginian sequence of Hole $416 \mathrm{~A}$, the organic matter enters into the final stages of maturity. This matter, however, is not mature enough to be considered a source of petroleum.

\section{ACKNOWLEDGMENT}

We thank J. B. Foresman of Phillips Petroleum Company for his review of and suggestions concerning the manuscript and C. P. Elston for her help in obtaining and assembling data presented herein.

\section{REFERENCES}

Erdman, J. G. and Schorno, K. S., 1978a. Geochemistry of carbon: Deep Sea Drilling Project Leg 40. In Supplement to Volumes $38,39,40$, and 41 : Washington (U.S. Government Printing Office), p. 651-658. , 1978b. Geochemistry of carbon: Deep Sea Drilling Project Leg 41. In Lancelot, Y., Siebold, E., et al., Initial Reports of the Deep Sea Drilling Project, v. 41: Washington (U.S. Government Printing Office), p. 849-854. 1978c. Geochemistry of carbon: DSDP Leg 44 . In Benson, W., Sheridan, R., et al., Initial Reports of the Deep Sea Drilling Project, v. 44: Washington (U.S. Government Printing Office), p. 605-616.

, in press. Geochemistry of carbon: Deep Sea Drilling Project, Leg 43. In Tucholke, B., Vogt, P., et al., Initial Reports of the Deep Sea Drilling Project, v. 43: Washington (U.S. Government Printing Office).

Philippi, G. T., 1974. The influence of marine and terrestrial source material on the composition of petroleum, Geochimica et Cosmochimica Acta, v. 36, 947-966. 